\section{Iearl Reider:}

The polar regions are very sensitive to environmental change, which makes their ice shields, neighboring lakes and oceans key targets for scientific drilling. In this volume of Scientific Drilling, we bring reports about the almost 4-km-deep ice coring in Antarctica (p. 41), which may reveal climate data back to around $1 \mathrm{Ma}$ as well as environmental observations from a lake that has been isolated below the Antarctic ice shield for more than $20 \mathrm{Ma}$. An extraterrestrial impact in northeast Siberia 3.6 Ma ago created Lake El'gygytgyn, which recorded the onset of Northern Hemisphere glaciations within the lake's oldest sediments, and traced within the younger sediments the ongoing waxing and waning of ice shields that persisted until today's interglacial (p. 29).

Ocean gateways like that of the Bering Sea are key areas in understanding long-term climate change and heat transport to the poles. The Bering Seaconnected to the Arctic Ocean in the north through the narrow Bering Strait and to the Pacific Ocean in the south across the Aleutian Island arc-was sampled by IODP Expedition 323 (p. 4) to address paleo-water mass distribution, terrigenous sediment infill, sea-ice history and other environmental parameters extending back to $5 \mathrm{Ma}$ or more.

Climate changes will impact all humans. However, a large part of Earth's population lives in areas that are affected by the most rapid and unpredictable environmental change: earthquakes. Scientific drilling has taken on the challenge to understand the processes at depths where earthquakes take place, and in line with this, a summary of the San Andreas Fault Zone Observatory at Depth (SAFOD) is presented on page 14. The Dead Sea, lowest point on Earth, is a place where tectonism, climate change and history come together in the most fascinating way. On page 46 we offer a progress report on the attempt to unearth the environmental history of this unique location and how it may have impacted the civilization and the histories of the region.

As part of the preparations for the new International Ocean Discovery Program, planned to start from late 2013, the current IODP is preparing for the most ambitious ever ocean drilling effort-to drill through the entire ocean crust and into the underlying mantle. At a recent workshop funded by the Sloan Foundation (p. 51), the technical feasibility of this challenging endeavor was reviewed, and the science targets were expanded to include the presence of carbon throughout the crust and within the upper mantle. Other workshops addressed plans to drill back in 'deep time' (p. 66) to examine environments and conditions for life at 3,500 Ma, or to examine potential deep fault systems that have been active due to the removal of former ice shields during the recent interglacial (p. 56).

Scientific drilling has clearly taken on the fascinating challenges of understanding Earth systems. Please enjoy from your armchair what this issue has to offer.
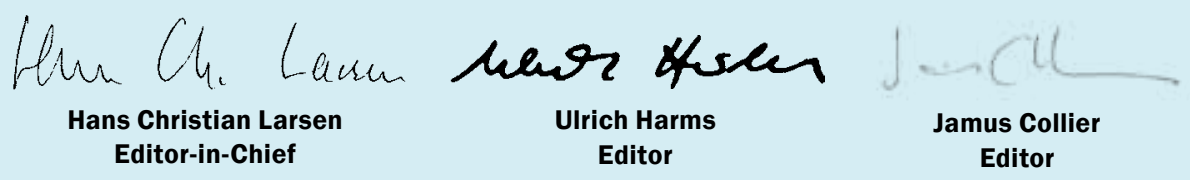

Front cover: The Deep Lake Drilling System (DLDS) in operation on the Dead Sea in late fall 2010. The ICDP drilling project in Israel, Jordan and Palestine.

Left inset: Two scientists match pieces of basalt collected at Site U1342 in the Bering Sea. (Photo: Carlos Alvarez Zarikian, IODP-TAMU)
Scientific Drilling is a semiannual journal published by the Integrated Ocean Drilling Program (IODP) with the International Continental Scientific Drilling Program (ICDP). The editors welcome contributions on any aspect of scientific drilling, including borehole instruments, observatories, and monitoring experiments. The journal is produced and distributed by the Integrated Ocean Drilling Program Management International (IODP-MI) for the IODP under the sponsorship of the U.S. National Science Foundation, the Ministry of Education, Culture, Sports, Science and Technology of Japan, and other participating countries. The journal's content is partly based upon research supported under Contract OCE-0432224 from the National Science Foundation.

Electronic versions of this publication and information for authors can be found at http://ww w.iodp.org/scientific-drilling/ and http://www.icdp-online.org/scientificdrilling/. Printed copies can be requested from the publication office.

IODP is an international marine research drilling program dedicated to advancing scientific understanding of the Earth by monitoring and sampling subseafloor environments. Through multiple drilling platforms, IODP scientists explore the program's principal themes: the deep biosphere, environmental change, and solid Earth cycles.

ICDP is a multi-national program designed to promote and coordinate continental drilling projects with a variety of scientific targets at drilling sites of global significance.

\section{Publication Office}

IODP-MI, Tokyo University of Marine

Science and Technology,

Office of Liaison and Cooperative

Research 3rd Floor,

2-1-6, Etchujima, Koto-ku, Tokyo

135-8533, JAPAN

Tel: $+81-3-6701-3180$

Fax: +81-3-6701-3189

e-mail: journal@iodp.org

url: www.iodp.org/scientific-drilling/

\section{Editorial Board}

Editor-in-Chief Hans Christian Larsen

Editors Ulrich Harms and Jamus Collier

Send comments to:

journal@iodp.org

Editorial Review Board

Gilbert Camoin, Keir Becker,

Hiroyuki Yamamoto, Naohiko Ohkouchi,

Stephen Hickman, Christian Koeberl,

Julie Brigham-Grette, and Maarten DeWit

\section{Copy Editing}

Glen Hill, Obihiro, Japan

Layout, Production and Printing

Mika Saido and Renata Szarek

(IODP-MI), and

SOHOKKAI, Co. Ltd., Tokyo, Japan

\section{IODP-MI}

Tokyo, Japan

www.iodp.org

Program Contact: Miyuki Otomo

motomo@iodp.org

ICDP

GFZ German Research Center For

Geosciences

www.icdp-online.org

Program Contact: Ulrich Harms

ulrich.harms@gfz-potsdam.de

All figures and photographs courtesy of the IODP or ICDP, unless otherwise specified. 